\title{
The Effect of Using the Cognitive Strategies on the Achievement and Practical Performance of Physiology (Modeling / Reciprocal teaching)
}

\author{
Miade Nazim Rashid \\ Assistant Professor. Middle Technical University, Technical medical Institute -Baghdad
}

\begin{abstract}
The research aims to know the impact of using the strategies of cognitive perception on the achievement and practical performance of physiology, and to achieve the goal of the research under the formulation of zero hypotheses: There is no statistically significant difference at the level of (05.0) between the average grades of students in the achievement of students of the three groups of physiology. There is no statistically significant difference at the level of (05.0) between the average grades of students in the practical performance of the students of the three groups of physiology. The research community consisted of the students of the first stage in the Technical Institute. The sample was randomly tested as it reached 45 students. The equivalence between the research groups was confirmed through the following variables: (Age, Intelligence). As for practical achievement, (15) objective test items were drafted covering the subject, and to ensure the validity of the test was presented to a number of experts specialized in education and teaching methods, and the validity and consistency of the discrimination factor and the difficulty factor and the effectiveness of alternatives to the test were calculated.
\end{abstract}

Keywords: Cognitive strategies, Modeling, Reciprocal teaching

\section{Introduction}

Recent studies emphasize that the student is the focus of the educational process and the adoption of work and experience a cornerstone of education ${ }^{1}$, and the Institute as one of the educational institutions provide a service to the community and seeks to develop and keep ${ }^{2}$ pace with technological development to educate the student to sound thinking and equipped with basic knowledge and skills. Physiology is one of the important subjects of life sciences, and despite its importance, this article is still taught by dumping and recipients by the teacher, and this is consistent with a lot of research and studies, but the use of regular methods in the field of education leads to poor understanding and correct perception, and weak Students have different thinking skills to solve the daily problems they face in the study ${ }^{4}$. Therefore, the development of mental abilities has become the main objective of the educational process in all countries of the world, as the progress of countries is measured by their ability to develop the minds of their children. To achieve this, many countries have made strenuous efforts and conducted many practical research aimed at regulating student thinking. ${ }^{25}$

Teaching methods are not the same but are the result of social needs and circumstances and demands are changing educational goals and concerns to meet the requirements of society ${ }^{7}$. And the importance of teaching methods and to achieve educational goals and the adoption of modern methods of teaching, including a symposium held at the University of Baghdad (1993), where recommended to contribute to the development of the educational process.

Therefore, studies and researches turned to metacognition theory, which cares for the student to monitor, control and learn. This helps to acquire different learning processes that encourage students to think and be able to solve their scientific problems ${ }^{7}$. This supracognitive strategy means thinking and helping the student positively in gathering, organizing, following up and evaluating information during the learning process. This supra-cognitive strategy contributes effectively to 
the learning and problem-solving process as it helps to achieve learning objectives and helps students to access cognitive processes.

\section{Laboratory and practical performance:}

\section{Genesis of laboratory work:}

Scientists in the field of laboratory work, such as Avicenna in medicine and optics, and Ibn Hayyan in chemistry, became famous in the field of chemistry. The idea of experiments began in Britain and Germany, and the teaching of science in the United States in 1874 was questioned.

Laboratories were set up in high schools and colleges in the late 18th century, believing that students would learn better by repeating the original experiences of Newton, Priestley and others.

\section{The performance:}

Performance is the unit of measurement of knowledge that the student shows in the situation and is the product of interaction, understanding and thinking that the student employs in the situation. What the student shows is the product of a comprehensive mental work that includes a response to the world and the knowledge system in an integrated environment.

\section{Performance includes:}

1. Performance Tasks: They are direct and realistic and require:

Performing a series of activities or performing a particular work.

Compound products (products) that achieve certain quality levels or present these products as an integrated unit separate from performance.

Performance Requirements:

The skill has three components and can even achieve practical performance: -
1. Information, knowledge and concepts.

2. Movements and coordination between movements.

3. Values and trends adopted by the student who is trained to perform the skill.

\section{Laboratory performance evaluation:}

The laboratory work falls under four aspects or aspects of laboratory activity:

1. Planning and design: involves students doing laboratory activities - forming questions - predicting results.

2. Performance: It includes students' laboratory achievements on experiments - observation, recording of data and drawings.

3. Analysis and interpretation: Data processing, interpretation of relationships, ask new questions.

4. Application: The student to make scientific predictions in new situations. (Zeitoun, 2007, 668)

\section{Research Procedures}

\section{Determine the research community:}

Determining the study population is one of the important methodological steps in educational research.

The research community was identified by the Technical Medical Institute / Baghdad for the academic year (2018-2019).

\section{The research sample:}

Research sample testing is one of the most important factors that influence experimental research. The research sample was selected from the students of the first stage of the Technical Medical Institute/ Baghdad. The sample was divided into (a) taught by supra-cognitive strategies (modeling), (b) taught by (reciprocal teaching), and (c) taught routinely. 
Table 1. Distribution of research sample among groups and number of students

\begin{tabular}{|l|l|l|l|l|}
\hline Groups & Group Name & $\begin{array}{l}\text { Number Of Students Before } \\
\text { Exclusion }\end{array}$ & $\begin{array}{l}\text { Number of } \\
\text { Students After } \\
\text { Exclusion }\end{array}$ & Final Number \\
\hline First Experimental Group & A & 19 & 5 & 14 \\
\hline Second Experimental Group & B & 18 & 2 & 16 \\
\hline Control Group & C & 17 & 2 & 15 \\
\hline
\end{tabular}

\section{Experimental design test:}

Experimental design is of great importance, as it ensures scientific accuracy

This study had two factors: the cognitive strategy (cognitive) (modeling) and (interactive teaching), so the experimental design was adopted three groups of two experimental groups and a control group.

Table 2. Experimental design was adopted three groups of two experimental groups and a control group.

\begin{tabular}{|l|l|l|l|}
\hline Groups & Equivalence & Independent Variable & The Dependent Variable \\
\hline First Experimental Group & Age & $\begin{array}{l}\text { Strategy Of Cognitive Supra- } \\
\text { Cognitive Modeling }\end{array}$ & Collection \\
\hline Second Experimental Group & Intelligence & Interactive Teaching & Practical Performance \\
\hline Control Group & & Normal Way & \\
\hline
\end{tabular}

\section{Equal groups:}

(A) Chronological Age in Months:

The mean age of the students was calculated in months, and extracted the mean of

\section{B- Intelligence:}

To find out the intelligence of the research sample. The Raven test is applied because it is characterized by honesty, consistency, usability and age group. After finding IQ scores (60), the mean was calculated for all the research groups, where the ratio was $(73.44,00.46,00.45)$.

\section{External safety of experimental design:}

Although groups were randomly tested, non-experimental variables that affect the safety of the experiment were attempted.

1. Adjust the contrast tools: Achievement test was used for the three research groups. 
2. Duration: The duration of the research was determined (the first course).

3. Quotas: Quotations were distributed two hours each week to ensure equal time allocated to the laboratory.

Search Requirements:

1. Determination of scientific material: The scientific material of physiology (course I) was determined.

2. Preparing the teaching plan.

3. Study Plan: It is a framework or set of procedures or are the steps organized to make the teaching process a success. (Abdulsalam, 2001, 72)

4. Preparation of experimental work guide: Then prepare experiments for conducting in the laboratory.

\section{Test stability:}

The stability of the test was calculated by Alfa Kronbach, where the stability was (83.0).

\section{Statistical means:}

1. Analysis of monotonous variance:

Variance analysis was used for the equivalence of the three research groups.

\section{Difficulty Coefficient:}

The difficulty factor for the objective paragraph was used for achievement test.

$$
\mathrm{P}=\frac{\mathrm{n}_{\mathrm{u}}+\mathrm{n}_{\mathrm{L}} \mathrm{n}_{\mathrm{u}}+\mathrm{n}_{\mathrm{L}}}{2 \mathrm{n} 2 \mathrm{n}}
$$

3. The power of discrimination:

$$
\mathrm{D}=\frac{\mathrm{p}_{\mathrm{u}}+\mathrm{p}_{\mathrm{L}} \mathrm{p}_{\mathrm{u}}+\mathrm{p}_{\mathrm{L}}}{\frac{1}{2}(\mathrm{n}) \frac{1}{2}(\mathrm{n})}
$$

4. Alpha-Cronbach equation: Achievement test coefficient.

5. Tukey Method: Indicates the difficulty of the differences between the results.

$$
\mathrm{Q}=\frac{\mathrm{x}_{1}-\mathrm{x}_{2} \mathrm{x}_{1}-\mathrm{x}_{2}}{\sqrt{\mathrm{MSW}} \sqrt{\mathrm{MSW}}}
$$

\section{Results}

\section{The first hypothesis:}

To achieve the first zero hypothesis (there are no statistically significant differences at the level of 0.00 between the average scores of students of the three groups studied by modeling and the second group by interactive teaching and the control group by the normal method) and the arithmetic mean of the three groups was calculated in the achievement test as shown In the table.

Table 3. Results of mono-variance analysis to show significant differences in achievement

\begin{tabular}{|l|l|l|l|l|l|l|}
\hline Contrast Source & $\begin{array}{l}\text { Total } \\
\text { Squares }\end{array}$ & $\begin{array}{l}\text { Degree of } \\
\text { Freedom }\end{array}$ & $\begin{array}{l}\text { Average } \\
\text { Squares }\end{array}$ & $\begin{array}{l}\text { Calculated } \\
\text { Value }\end{array}$ & $\begin{array}{l}\text { Tabular } \\
\text { Value }\end{array}$ & $\begin{array}{l}\text { Statistical } \\
\text { Significance }\end{array}$ \\
\hline Between Groups & 43,513 & 2 & 22,256 & & & \multirow{2}{*}{0.05} \\
\cline { 1 - 4 } Within Groups & 13,366 & 42 & 77,7 & 35,28 & 1503,3 & \\
\hline Total & 58,880 & 2 & & & & \\
\hline
\end{tabular}


The above table shows that the calculated Y-value was (35.28) and the tabular Y-value (1503.3), that is, the calculated $\mathrm{Y}$-value is greater than the tabular Y-value, which affects the existence of statistically significant differences in the achievement of the three research groups. There was a statistically significant difference, so the T method was used to compare two equal media to identify the differences. (Al-Bayati, 2008, 264). Therefore, the tabular value (Q) (38.0) was calculated, as well as the calculated $(\mathrm{Q})$ value (43.3) between the two media. This indicates that there is no statistically significant difference between the first and second experimental groups in the collection.

Table 4. The results of the analysis of comparison between the differences of the average of the three groups

\begin{tabular}{|c|c|c|c|c|c|}
\hline the group & Averages & $\begin{array}{l}\text { The difference } \\
\text { between } \\
\text { averages }\end{array}$ & $\begin{array}{l}\text { The calculated } Q \\
\text { value }\end{array}$ & $\begin{array}{l}\text { The } Q \text { value } \\
\text { is }\end{array}$ & $\begin{array}{l}\text { tabular } \\
\text { Significance at } 0.05\end{array}$ \\
\hline Total Experimental 1 & 3,20 & \multirow{2}{*}{3,0} & \multirow{2}{*}{38,0} & \multirow{2}{*}{43,3} & \multirow{2}{*}{ NonFunction } \\
\hline Total Experimental 2 & 6,20 & & & & \\
\hline Total Experimental 1 & 6,20 & \multirow{2}{*}{0,7} & \multirow{2}{*}{2,9} & \multirow{2}{*}{43,3} & \multirow{2}{*}{ Function } \\
\hline Total Controls & 3,13 & & & & \\
\hline Total Experimental 2 & 6,20 & \multirow{2}{*}{2,7} & \multirow{2}{*}{6,9} & \multirow{2}{*}{43,3} & \multirow{2}{*}{ Function } \\
\hline Total Controls & 3,13 & & & & \\
\hline
\end{tabular}

The table shows that the value of $(\mathrm{Q})$ calculated between the first and control groups (2.9) is greater than the table value (Q) of (43.3), and this shows a statistically significant difference between the first experimental and control groups in favor of the experimental group. First.

In addition, the value of $(\mathrm{Q})$ calculated between the first and control groups of (6.9) was greater than the tabular value of $(\mathrm{Q})$ of (43.3). This indicates that there is a statistically significant difference in the achievement between the second and control experimental group. In favor of the second experimental group.

2- The second zero hypothesis: which provides (the absence of statistically significant differences at the level of 0.0 .0 between the average degrees of practical performance of students of the three groups).

Table 5. The results of the analysis of unilateral variation to show individual differences in practical performance among students of the three groups

\begin{tabular}{|l|l|l|l|l|l|l|}
\hline Contrast Source & $\begin{array}{l}\text { Total } \\
\text { Squares }\end{array}$ & $\begin{array}{l}\text { Degree of } \\
\text { Freedom }\end{array}$ & $\begin{array}{l}\text { Average } \\
\text { Squares }\end{array}$ & $\begin{array}{l}\text { Calculated } \\
\text { Value }\end{array}$ & $\begin{array}{l}\text { Tabular } \\
\text { Value }\end{array}$ & $\begin{array}{l}\text { Statistical } \\
\text { Significance }\end{array}$ \\
\cline { 1 - 5 } Between Groups & 40,371 & 2 & 20,185 & & \multirow{2}{*}{0.05} \\
\cline { 1 - 4 } Within Groups & 60,204 & 42 & 89,4 & 04,37 & 1503,3 & \\
\cline { 1 - 5 } Total & 00,576 & 2 & & & & \\
\hline
\end{tabular}


The table shows that the calculated Y-value was (04.37) and the tabular Y-value (1503.3), that is, the calculated $\mathrm{Y}$-value is greater than the tabular Y-value. This indicates that there are statistically significant differences at the level of (05.0). In the practical performance of the three research groups. Using $\mathrm{T}$ method to identify differences between groups. Table (8) illustrates this.

Table 6. The results of the comparison analysis between the mean differences for the three groups in the practical performance

\begin{tabular}{|c|c|c|c|c|c|}
\hline The Group & Averages & $\begin{array}{l}\text { The Difference } \\
\text { between averages }\end{array}$ & $\begin{array}{l}\text { The Calculated } Q \\
\text { value }\end{array}$ & The $Q$ value is & $\begin{array}{l}\text { Tabular } \\
\text { Significance at } 0.05\end{array}$ \\
\hline Total Experimental 1 & 6,16 & \multirow{2}{*}{2,3} & \multirow{2}{*}{6,5} & \multirow{2}{*}{43,3} & \multirow{2}{*}{ Function } \\
\hline Total Experimental 2 & 8,13 & & & & \\
\hline Total Experimental 1 & 6,16 & \multirow{2}{*}{0,7} & \multirow{2}{*}{2,12} & \multirow{2}{*}{43,3} & \multirow{2}{*}{ Function } \\
\hline Total Controls & 6,10 & & & & \\
\hline Total Experimental 2 & 8,13 & \multirow[b]{2}{*}{2,4} & \multirow[b]{2}{*}{3,7} & \multirow[b]{2}{*}{43,3} & \multirow[b]{2}{*}{ Function } \\
\hline Total Controls & 6,10 & & & & \\
\hline
\end{tabular}

The table shows that the calculated value of Q (6.5) is greater than the tabular value (Q) of (43.3). This indicates that there is a statistically significant difference between the first and second groups in practical performance and for the benefit of the first experimental group.

The table also shows that the value of $(\mathrm{Q})$ calculated between the first experimental group and the control group of (2.12) is greater than the value of the $(\mathrm{Q})$ tabular value of (43.3). First experimental group.

\section{Conclusions}

The researcher reached the following conclusions:

1. Teaching according to the strategy of cognitive supra-cognitive has had an impact in increasing students of the Technical Technical Institute

2. Teaching according to supra-cognitive strategies of practical performance has had an effective effect in raising the level of students.

3. Teaching according to this strategy requires more time and effort for the teacher and student than is required when using other teaching methods.
4. Teaching according to supra-cognitive strategies has affected students who have awareness of their knowledge and are more organized in their performance of experience than students who do not.

Financial Disclosure: There is no financial disclosure.

Conflict of Interest: None to declare.

Ethical Clearance: All experimental protocols were approved under the Technical medical Institute -Baghdad and all experiments were carried out in accordance with approved guidelines.

\section{References}

1. Abu-Jadu SM. Educational Psychology, Dar AlMasirah for Publishing and Distribution, Second Edition, Jordan. 2000.

2. Abu Jadu MA, Mohammed B. The teaching of thinking theory and practice, Dar Al-Masirah for Publishing and Distribution, first edition, Amman. 2007.

3. Abu Rayash HM. cognitive learning, Dar AlMasirah for publication and distribution, first 
edition, Amman. 2007.

4. Abu Ghazal MM. Theories of Human Development and its Educational Applications, Dar Al-Masirah for Publishing and Distribution, First Edition, Amman. 2006.

5. Imam M. evaluation and measurement, House of wisdom for printing and publishing, second edition, Baghdad. 1988.

6. Volcanic N. the effect of teaching using multiple intelligence strategies and the six layers of K.W.L on the achievement and communication and mathematical interdependence of third grade students in the city of Mecca, unpublished doctoral thesis, Saudi Arabia. 2007.

7. Jazea JM, Hamid G, Identification of the educational competencies of the teacher of geography in secondary schools from the perspective of teachers of geography, Journal of Basra Research, part (2).

8. Camel M, Zaid A. Methods of Disclosing the Outstanding and Developing Thinking and Creativity, UAE. 2003.

9. Al-Harthy M. The Effectiveness of Interactive Teaching Strategy in Developing Metacognition Skills in Reading for Secondary School Students, Unpublished Master Thesis, UAE. 2008.

10. Al-Hailah M. The Effect of Artistic Activities on Innovative Thinking among the Foundation Stage Students, Journal of the Educational Research Center, No. (19), Qatar University. 2001.

11. Khattab A. The Effect of Using Metacognitive Strategies in Teaching Mathematics on Achievement and Developing Creative Thinking among the Pupils of the Second Cycle of Basic Education, Unpublished Master Thesis, Ain Shams. 2007.

12. Khattabiya A. Science Education for All, Dar AlMasirah for Publishing and Distribution, First Edition, Amman. 2005.

13. Khalili K. Achievement of preparatory education students, Ministry of Education, first edition, Manama.

14. Darwazah A. the effect of activating the epistemological strategies on the level of reading and reading comprehension, An-Najah University Journal for Research. 1995; Volume (3): No. (9).

15. Al-Dulaimi B. Mathematical Strength and its Relationship with Metacognitive Skills for
Secondary School Students, Ph.D. Dissertation, College of Education / Ibn Al-Haytham, Baghdad. 2010.

16. Al-Rikabi, Q. the effectiveness of the synthesis model in the achievement of second grade students average and their motivation to learn biology, Master Thesis, University of Baghdad. 2010.

17. Zakaria O. pre-school strategies, Arab Gulf Magazine, No. 22, Kuwait. 1978.

18. Al-Zind, W. Educational Designs, Theoretical Roots, Models of Scientific Applications, and Arab and International Researches, First Edition, Special Education Academy Publications Series, Saudi Arabia. 2004.

19. Zeitoun, Hassan Hussein, the nature of science and the structure of its applications in scientific education, Dar Ammar for printing and publishing, the first edition, Amman. 1988.

20. Zeitoun H. Thinking an applied vision in the development of minds of notebooks, first edition, Egypt. 2003.

21. Samarrai, Faek Fadel Ahmed, the impact of the use of diagnostic tests in stimulating the sixth scientific students in the subject of calculus, Journal of Fath, Volume (2), Issue (3), Teachers College, Mustansiriya University, Diyala. 1998.

22. Shehata Z. Dictionary of Educational and Psychological Terminology, Egyptian-Lebanese House, First Edition, Cairo. 2003.

23. Sheikh S. The psychological foundations for the use of teaching aids, Adult Learning Leadership Training Center, First Edition, Bahrain. 1990.

24. Al-Saffar A. Modern Trends in Teaching School Mathematics, First Edition, Baghdad. 1986.

25. Al-Titi M. Development of Creative Thinking Capabilities, Dar Al-Masirah for Publishing, Distribution and Printing, First Edition, Jordan. 2001.

26. Al-Zaher, Zakaria Mohammed, Development of creative thinking abilities, Dar Al-Masirah for Publishing and Distribution, First Edition, Amman. 2002.

27. Abdul Bari M. reading comprehension strategies based on the theory and practical applications, Dar Almassira for publication and distribution, first edition. 2010.

28. Abdel Salam M. Teaching Science and the 
requirements of the times, Dar Al Fikr for Printing and Publishing, Cairo. 2006.

29. Abdel-Karim, Sahar Mohamed, the effectiveness of teaching according to Piaget Wijonsky theory in the achievement of some physical concepts and the ability to formal deductive reasoning among students of the first secondary school, the fourth scientific conference of the Egyptian Association for Scientific Education, Egypt. 2000.

30. Obaid E. The Impact of Inductive Thinking and Free Thinking Strategies in Critical Thinking, Supercognitive Perception and Achievement among Basic Stage Students in Biology, Unpublished PhD Thesis, Amman. 2004. 